\author{
Golinko, V.I., Cheberiachko, S.I., and Yavorska, 0.0. \\ National Mining University, \\ 19, Yavornytskoho Ave., Dnipro, 49600, Ukraine, \\ +380567447339, rector@nmu.org.ua
}

\title{
EVALUATION OF THE PROTECTIVE PROPERTIES OF FILTERING HALF-MASKS BY MEASURING PRESSURE DIFFERENCE
}

Introduction. An important characteristic of respirator is the capability of its half-mask to protect the respiratory organs against the surrounding contaminated atmosphere due to a tight half-mask-face contact.

Problem statement. Keeping a constant pressure difference under the mask is a low-cost and simple method of alternative diagnostics of half-mask protective properties involving special-purpose test aerosols. The method is based on the determination of the air amount entrained through the gaps while generating rarefaction within the under-mask area. However, there have been no recommendations on the use of the method for evaluating the insulating properties of lightweight filtering half-masks from under which it is impossible to evacuate air.

Purpose is to represent a simplified method with measuring the rarefaction under a filtering half-mask making possible to determine its insulating properties and protection coefficient.

Materials and Methods. Protection coefficient of respirator can be evaluated in terms of air amount passing through the filtering material and gaps with the preset coefficient of penetration and suction. The latter is calculated as coefficient of aspiration into the gap of the preset length. Air consumption is determined experimentally as pressure difference between the half-mask mounted tightly on a dummy and the tubes of preset diameter positioned along the obturation line.

Results. A calibration line of the relation between the pressure difference and the air consumption through a gap for the filtering half-masks has been developed. Coefficients of insulation and protection of Lepestok-type respirators have been calculated. The protection coefficients have been established to proportionally depend on the ratio of air consumption through a filter and gaps between the face and the half-mask along the obturation line.

Conclusions. It has been proved that the methods for determining the protective properties of filtering half-masks in terms of measuring pressure difference may be used as a low-cost alternative to expensive diagnostics of the quality of respiratory protective devices. Also, they can be employed for selecting and training workers to properly use the respirators under manufacturing conditions in accordance with EN 529:2006 requirements.

Keywords: concentration of harmful substances, coefficient of penetration, air consumption, protective properties, and filtering half-mask.

\section{TOPICALITY}

In the opinion of experts in the field of air filtration, the application of fibrous filters is the simplest, the most reliable, and economical means to capture highly dispersed aerosols [1]. Numerous designs with the use of colmasels, fibers of lavsan, polypropylene, polyacrylonitrile etc. are

(C) GOLINKO, V.I., CHEBERIACHKO, S.I., and YAVORSKA, O.O., 2018 available [2]. Petrianov filters (PFs) hold a specific place among them. A high efficiency under the conditions of comparatively low hydrodynamic resistance is their characteristic feature. The unique properties of materials used for the PFs (i.e. those bearing a high electrostatic charge within their fibers) have enabled to develop light and comfortable respiratory protective devices (RPDs). They are characterized by high breathing resistance; moreover, they can suppress dif- 
ferent aerosol types [3]. However, the capability of half-mask to protect respiratory organs against dusty atmosphere due to a tight fitting to face is another important characteristic. Possible leakage of polluted air along the obturation line deteriorates significantly the RPDs protective efficiency. That is why, the evaluation of protective properties of filtering half-masks at the stage of their design and laboratory tests is a topical issue.

\section{ANALYSIS OF SCHOLARLY RESEARCH SOURCES}

The leakage between the face and the halfmask is possible to be detected using either qualitative or quantitative method. The qualitative test of respirators is based on certain subjective reactions of the sense organs to strong smell of sprayed saccharine aerosols, Bitrex, and isoamyl acetate. The research papers $[4,5]$ contain the detailed description of this test. Different individual sensitivity threshold that, in some cases, can exceed the maximum permissible concentration of aerosol is disadvantage of the methods.

The qualitative methods are based on instrumental tests. They are more accurate as they apply special-purpose equipment fixing the available aerosol leakage under half-masks. The most popular method is to determine the coefficient of suction according to DSTU EN 149. The essence is to estimate the ratio of the external specialpurpose test aerosol concentration to the undermask concentration; in case of filtering halfmasks. It is the difference between the penetration coefficients of the respirator and the filtering component [6]. However, the procedure requires rather expensive and complex devices as well as trained specialists. Moreover, the obtained results will depend not only upon particle size and testing method but also upon the conditions of mixing the flows under the half-mask, the position of sampling probe, and the gap along the obturation line, if any [7-9]. The method disadvantage is the impossibility to evaluate the protective properties under working conditions as to obtain the average coefficient of penetration. It is re- quired to have multiple sample probes for every testee that is quite costly, labor-consuming, and impracticable [10]. That is why, a simpler and more accurate method to evaluate the protective properties of respirators with the help of constant pressure control has been developed. The idea of the method is in evaluating the amount of air leakage in the context of applied under-mask rarefaction with the help of a small-size pump and a pressure sensor [11]. A test person puts on a respirator (which filters are closed tightly with special-purpose headers) and holds his/her breathe for some seconds; the pump connected through the valve system is activated and evacuates some air. In this context, rarefaction is recorded by the pressure sensor. If there are any gaps between the face and the half-mask, then the rarefaction is reduced, the pump is activated, with air evacuated up to the specified rarefaction. The amount of the evacuated air precisely corresponds to the leaked one. The whole procedure takes only $7-10 \mathrm{~s}$ [12]. The method is notable for a relatively low cost of the equipment; though, it cannot be applied for the filtering half-masks. Thus, the problem of its improvement as well as the determination of the protective properties of filtering half-masks has arisen.

The research objective is to represent a simplified method for evaluating the protective properties of filtering half-masks based on the measurement of rarefaction within the under-mask area. The aim is also to compare the efficiency of widespread half-masks Lepestok and Snezhok manufactured in Ukraine.

\section{THEORETICAL PART}

While using the respirator, two airflows enter the under-mask area. The first (main) flow $Q_{0}$ goes through the filters while the second one $Q_{n}$ goes through the gaps being, as a rule, minor openings between the face and the mask (also, leakage may be a result of exhalation valve defects (Fig. 1)).

The respirator protective level is determined by the coefficient of protection (ratio of external 


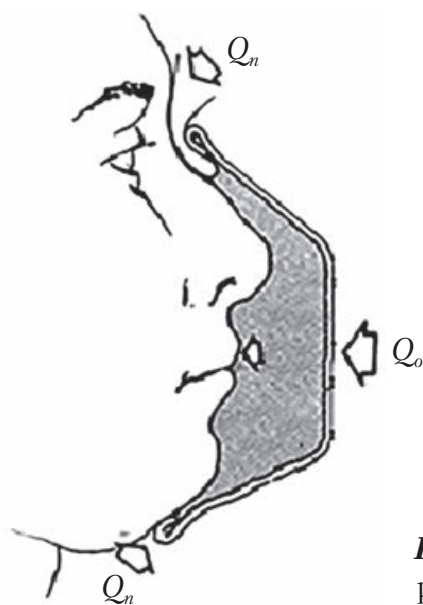

Fig. 1. Scheme of airflows penetrating under the mask

contaminator concentration, i.e. $C_{N}$, to the under-mask $C_{n}$ concentration)

$$
K_{z}=\frac{C_{N}}{C_{n}} .
$$

The amount of under-mask contaminator $C_{n}$ depends upon the consumption of the air penetrating through filter $Q_{0}$ and gaps $Q_{n}$ as well as upon the coefficients of efficiency of aerosol capturing $\eta_{c}$ and suction of the nonpurified air due to leakages along the obturation line $\eta_{n}$

$$
C_{n}=\frac{C_{N} Q_{0}\left(1-\eta_{c}\right)+C_{N} Q_{n}\left(1-\eta_{n}\right)}{Q_{0}+Q_{n}} .
$$

Thus, taking into consideration formula (2), the coefficient of respirator protection will be equal to

$$
K_{z}=\frac{1+\frac{Q_{n}}{Q_{0}}}{\frac{Q_{n}}{Q_{0}}\left[\left(1-\eta_{c}\right)+\left(1-\eta_{n}\right)\right]} .
$$

While performing the quantitative evaluation of the insulating properties with the help of test aerosol, the high-efficiency particle filters applied in the respirators have been established to capture, at least, $99.97 \%$ aerosol $\left(\eta_{c} \equiv 1\right)$. The measured $K_{z}$ takes into account only penetration through gaps $Q$. Hence, equation (3) makes it possible to obtain an expression to evaluate the coefficient of insulation:

$$
K_{u}=\frac{1+K_{p}}{\eta_{n}},
$$

where $K_{p}$ is the coefficient of air consumption characterizing the tightness of mask-face contact, $K_{p}=Q / Q_{n}$.

The previous studies have demonstrated that air penetration through the filter is of laminar character; thus, the airflow through filter $Q_{0}$ depends linearly upon the pressure difference within the filter, if there are no gaps

$$
Q_{0}=f_{f} \Delta p \text {, }
$$

where $f_{f}$ is the coefficient of filter resistance determined experimentally.

The relation between the air consumption through gap $Q_{n}$ and pressure difference $\Delta p$ can be represented as follows

$$
Q_{n}=f_{z}\left(\Delta p_{z}-\Delta p\right),
$$

where $f_{z}$ and $\Delta p_{z}$ are the coefficient of gap resistance and pressure difference within the halfmask in terms of possible availability of gaps. Taking into consideration formulas (5) and (6), coefficient of consumption can be determined as

$$
K_{p}=\frac{\alpha \Delta p}{\left(\Delta p_{z}-\Delta p\right)},
$$

where a is the coefficient of respirator resistance determined from the calibration curve, $a=f_{f} / f_{z}$.

The dependence of consumption coefficient $K_{p}$ upon pressure difference $\Delta p$ shows the air consumption through the gaps, i.e. the protective properties of half-mask. Having inserted the formula (7) into the formula (3), we obtain:

$$
K_{3}=\frac{10\left[\frac{\Delta p_{z}}{\Delta p}+(1-\alpha)\right]}{\alpha\left[\left(1-\eta_{c}\right)+\left(1-\eta_{n}\right)\right]} .
$$

\section{EXPERIMENTAL PART}

A trial stand (Fig. 2) to measure the pressure difference within the respirator mounted on head dummy consists of the following components: a head dummy, an electronic differential vacuum micro manometer (Testo 512, measurement range is $0 \ldots 200 \mathrm{~Pa}$, a response time is $0.2 \mathrm{~s}$; manufactured by Testo $A G$, Germany); Microsoft Office Excel software; a piston pump with $2.5 \mathrm{dm}^{3} /$ cycle and $12 \mathrm{cycle} / \mathrm{min}$ air consumption. The filtering 
respirators Lepestok of FFP2 class were selected for testing the protective properties (Fig. 3).

An aspirator was used to generate rarefaction identical to the inhalation process. The system is adjusted so that in terms of maximum air consumption through the respirator filters the amount of air coming through the gap will make up $2 \%$ of general consumption.

The basic stage of the research involved the measurements of air consumption and rarefaction under the filtering half-mask for six head dummies. Their sizes corresponded to the parametric table for the selection of participants while testing the protective properties of respirators and checking their meeting the standard requirements (Table 1).

Thus, 5 closed tubes of various diameters, from 2.5 to $14 \mathrm{~mm}$, were set between the half-mask and the human-face dummy; the half-mask was tightened along the obturation line with the help of liquid silicone. That way, the air consumption and rarefaction under the filtering half-mask in the process of sequential opening of tubes were measured (Fig. 3). According to the results, a calibration curve of the interaction between the pressure difference $\Delta p$ and the air consumption through the gap $Q_{n}$ was plotted. The standard deviation of air consumption through the gap varied up to $3 \%$ of the average value - the dimensions are indicated in Table 1.

The test stages are as follows:

1. Half-masks were mounted on head dummy sequentially.

2. As the vacuum micro manometer is connected, the airflow consumption and the pressure difference are measured in terms of inhalation for

Table 1

Sizes of Head Dummies Used While Testing

\begin{tabular}{|c|c|c|c|}
\hline \multirow{2}{*}{ Face height, mm } & \multicolumn{3}{|c|}{ Face width, mm } \\
\cline { 2 - 4 } & $\begin{array}{c}129-139 \\
\text { (zone 1) }\end{array}$ & $\begin{array}{c}140-145 \\
\text { (zone 2) }\end{array}$ & $\begin{array}{c}146-155 \\
\text { (zone 3) }\end{array}$ \\
\hline $136-126$ & - & $1(2)$ & - \\
$125-116$ & $1(1)^{*}$ & $1(3)$ & $1(4)$ \\
\hline
\end{tabular}

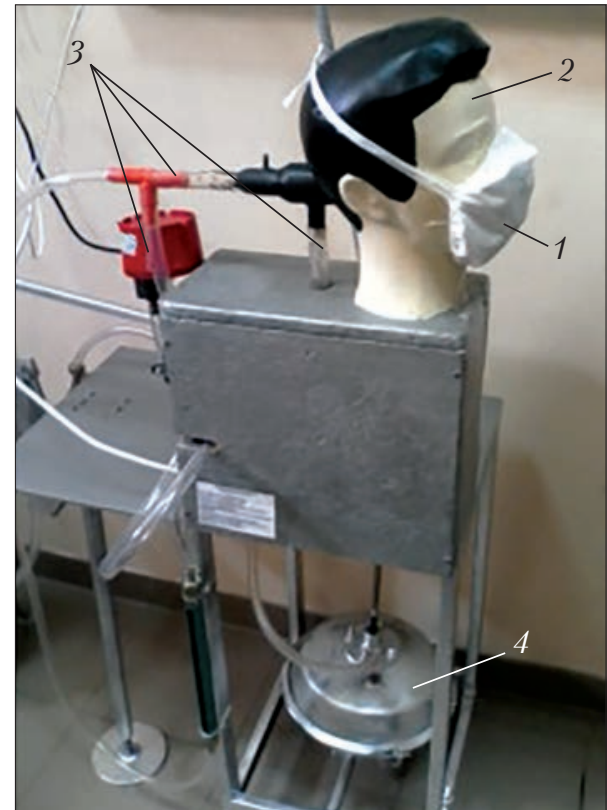

Fig. 2. Determination of leakages through the gaps (respirators of standart type): 1 - respirator; 2 - head dummy; 3 - air outlet ports; 4 - piston pump

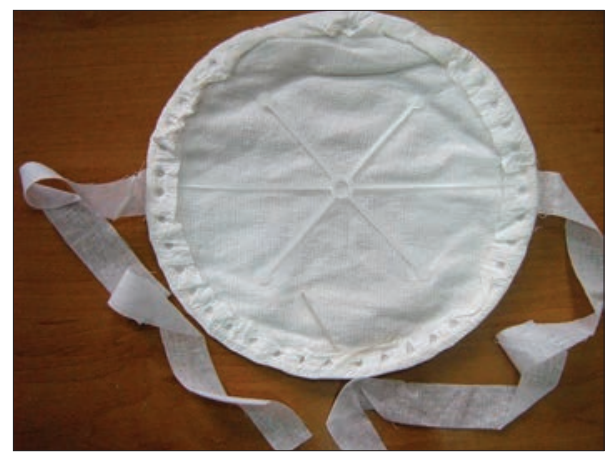

Fig. 3. Respirators for the tests Lepestok

different head positions (the figures indicate the positions of head dummy while testing: $1-$ standard position of the dummy; 2 - the dummy lies on its right side; 3 - the dummy lies on its left side; 4 - the dummy is turned backward; 5 - the dummy leans forward).

After that, the closed tubes of various diameters are mounted between the half-mask and the dummy along the obturation line.

3. The obturation line is tightened with the help of liquid silicone. 


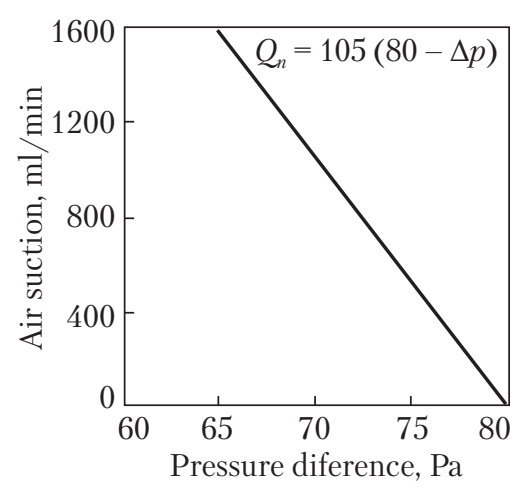

Fig. 4. Calibration line of the relation of pressure difference $\Delta p$ and air consumption through the gap $Q_{n}$ for the filtering half-masks of Lepestok type

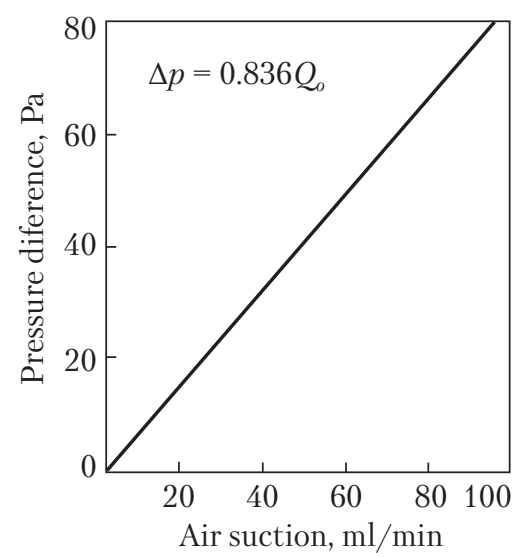

Fig. 5. Calibration line of the relation of pressure difference $\Delta p$ and air consumption $Q_{0}$ through the filtering half-mask of Lepestok type

4. The initial half-mask resistance at an air consumption of $95 \mathrm{l} / \mathrm{min}$ with the closed tubes is measured.

5. The tubes are opened sequentially, with the under-mask rarefaction $\Delta p$ measured.

6. According to the obtained data, the dependence of pressure difference $\Delta p$ on air consumption through the gaps $Q_{n}$ and filters $Q_{n}$ is found (Fig. 4, 5);

7. Taking into consideration the calibration curves, $K_{p}, K_{u}$, and $K_{z}$ characterizing the insulating and protective properties of the respirator are calculated.

The calculation stages are as follows:

1. $K_{p}$ is calculated as index of the insulating properties of the respirator taking into account the obtained calibration curve and air consumption.

2. According to DSTU EN 149, the penetration coefficient of the filtering material used to manufacture filters for the second protective class respirators is taken to be, at most, $6 \%$ at an air consumption of $95 \mathrm{l} / \mathrm{min}$.

3. The coefficient of suction through the gap along the obturation line is calculated according to the formulas [12]

$$
\begin{gathered}
\eta_{n}=1-5.5 k^{2 / 3}+3.77 k, \text { at } k<0.009, \\
\eta_{n}=0.819 \exp (-11.5 k)+0.0975 \exp (-70.1 k), \\
\text { at } k>0.009,
\end{gathered}
$$

where $k=\frac{D L}{Q_{l}} ; L$ is the tube length (being equal to $15 \mathrm{~mm}$ while testing), $\mathrm{m}$; $D$ is the coefficient of diffusion $\left(1.46 \cdot 10^{-5} \mathrm{~m}^{2} / \mathrm{s}\right)$; and $Q_{l}$ is air consumption through a tube, $\mathrm{m}^{3} / \mathrm{s}$.

\section{RESULTS OF THE RESEARCH}

Table 2 shows the measured values of pressure difference for Lepestok-type respirator and various dummies.

Table 3 shows the results of air consumption calculations along the obturation line according to the formula (6). According to DSTU EN 149, the penetration coefficient of the filtering material used to manufacture filters for the second protection class respirators should not exceed $6 \%$ at an air consumption of $95 \mathrm{l} / \mathrm{min}$. The coefficient of suction through the gap along the obturation line can be calculated using the formulas [13].

Table 4 gives the values of the calculated coefficients of air consumption, insulation, and protection of respirators.

\section{DISCUSSION OF THE RESULTS}

Fig. 4 represents the relation between the air consumption through the gaps and the pressure difference for the filtering half-mask of Lepestok type. Each point in the graph is the value of five measurements. While using the approximation of the obtained results, we have got coefficient a required to determine the consumption of air pene- 
Values of Pressure Difference within Lepestok Type Respirators

Mounted on Dummies

\begin{tabular}{|c|c|c|c|c|c|c|c|}
\hline \multirow{2}{*}{$\begin{array}{c}\text { Number } \\
\text { of zone }\end{array}$} & \multirow{2}{*}{$\begin{array}{c}\text { Number } \\
\text { of dummy }\end{array}$} & \multicolumn{5}{|c|}{ Pressure difference within the respirator for various head dummy positions, $\Delta p$, Pa } \\
\cline { 3 - 7 } & 1 & 2 & 3 & 4 & 5 & Average \\
\hline 1 & 1 & 72 & 70 & 73 & 73 & 72 & $72.0 \pm 1.0$ \\
2 & 2 & 74 & 71 & 72 & 73 & 73 & $72.6 \pm 0.9$ \\
& 3 & 73 & 75 & 72 & 74 & 73 & $73.4 \pm 0.9$ \\
3 & 4 & 74 & 76 & 76 & 74 & 75 & $75.0 \pm 0.8$ \\
& 5 & 70 & 71 & 73 & 71 & 72 & $71.4 \pm 0.9$ \\
AVERAGE & 6 & 68 & 71 & 70 & 71 & 71 & $70.2 \pm 1.1$ \\
\hline
\end{tabular}

trating through the half-mask gaps (the half-mask is on head dummies). It should be noted that the calibration graph is necessary for each type of filtering half-masks as they can differ in their filter resistance, which considerably affects the suction.

The experiment results indicate that in the cases of 5 and 6 , the respirator has demonstrated the worst results. It shows that if the head size is rather large, it is hard to provide the required insulating properties along the obturation line. One of the possible reasons is the necessity of individual assembly of Lepestok respirator as it is available in the form of "semi-finished product". It is rather difficult to assemble the respirator properly without adequate training. In most cases, the user does not pay attention to the arrangement of folds along the perimeter of obturator; that results in the formation of additional channels for unfiltered air suction (Fig. 6). The conclusion also confirms the test results for the insulating and protective properties of frame Snezhok-type respirator which final calculation is presented in Table 5.

The analysis of obtained data demonstrates comparatively similar results; in our opinion, this tells about fewer gaps formed along the obturation line.

Similar conclusions have been made in [14]. The research shows that the respirator of $L e$ -
Relation between the Pressure Difference and the Suction within the Half-Masks

\begin{tabular}{|c|c|c|c|}
\hline $\begin{array}{c}\text { Number } \\
\text { of dummy }\end{array}$ & $\begin{array}{c}\text { Average pressure } \\
\text { difference } \\
\text { within the } \\
\text { half-mask fixed } \\
\text { air-tightly on } \\
\text { dummy, } \Delta p, \mathrm{~Pa}\end{array}$ & $\begin{array}{c}\text { Average } \\
\text { pressure } \\
\text { difference for } \\
\text { the half-masks } \\
\text { on dummies, } \\
\Delta p, \mathrm{~Pa}\end{array}$ & $\begin{array}{c}\text { Air } \\
\text { consumption } \\
\text { along the } \\
\text { obturation line } \\
Q_{n}, \mathrm{ml} / \mathrm{min}\end{array}$ \\
\hline 1 & & $72.0 \pm 1.0$ & 840 \\
2 & & $72.6 \pm 0.9$ & 777 \\
3 & & $73.4 \pm 0.9$ & 693 \\
4 & $80.1 \pm 0.8$ & $75.0 \pm 0.8$ & 525 \\
5 & & $71.4 \pm 0.9$ & 903 \\
6 & & $70.2 \pm 1.1$ & 1029 \\
\hline
\end{tabular}

Table 4

Calculations of Insulation and Protection Coefficients for the Lepestok-Type Respirators

\begin{tabular}{|c|c|c|c|c|c|}
\hline $\begin{array}{c}\text { Number } \\
\text { of } \\
\text { dummy }\end{array}$ & $\begin{array}{c}\text { Air } \\
\text { consumption } \\
\text { along the } \\
\text { obturation } \\
\text { line } \\
Q_{n} \text { ml/min }\end{array}$ & $\begin{array}{c}\text { Equivalent } \\
\text { diameter } \\
\text { of hole } \\
\text { along the } \\
\text { obturation } \\
\text { line, } d, \mathrm{~mm}\end{array}$ & $\begin{array}{c}\text { Coeffi- } \\
\text { cient } \\
\text { of con- } \\
\text { sumption } \\
K_{p}\end{array}$ & $\begin{array}{c}\text { Coeffi- } \\
\text { cient of } \\
\text { insula- } \\
\text { tion } K_{u}\end{array}$ & $\begin{array}{c}\text { Coeffi- } \\
\text { cient of } \\
\text { protec- } \\
\text { tion } \\
K_{z}\end{array}$ \\
\hline 1 & 840 & 3.0 & 1.1 & 1.1 & 34.2 \\
2 & 777 & 2.5 & 1.2 & 1.2 & 35.9 \\
3 & 693 & 2.0 & 1.4 & 1.4 & 38.3 \\
4 & 525 & 1.8 & 1.9 & 1.9 & 44.1 \\
5 & 903 & 3.2 & 1.0 & 1.0 & 32.5 \\
6 & 1029 & 3.5 & 0.9 & 0.9 & 29.6 \\
\hline
\end{tabular}



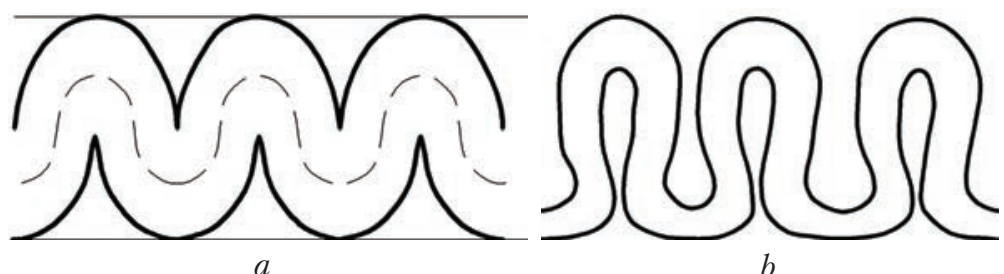

Fig. 6. Arrangement of corrugations within the obturator of Lepestok-type filtering respirators in terms of correct $(a)$ and incorrect $(b)$ assembly pestok type provides the stated level of protection only for $70 \%$ of the testees. The authors pointed out the importance of proper respirator preparation. It appeared that the further tests showed better results. It should be noted that those testees learnt how to assemble the respirator correctly and to fix it on their faces. Attention was paid to a uniform arrangement of the obturator folds along the perimeter of assembled respirator, to a proper fit between the metal carrier and the nasal bridges, and to positioning of main-set strings on the back of their heads. Summing up the carried out studies, the authors emphasize that the protective level of Lepestoktype respirator depends mostly upon the level of user's preparation and training.

It should be mentioned that according to DSTU EN 529:2006 "Recommendations on the selection, use, and maintenance of RPD" approved by Resolution No.179 of 29.06.2006 of the Cabinet of Ministers of Ukraine "On the approval and cancellation of the national standards of Ukraine”, which came into effect since 01.10.2007,

Table 5

Calculation Results of Insulation and Protection Coefficients for the Snezhok-Type Respirators

\begin{tabular}{|c|c|c|c|c|c|}
\hline $\begin{array}{c}\text { Number } \\
\text { of } \\
\text { dummy }\end{array}$ & $\begin{array}{c}\text { Air } \\
\text { consumption } \\
\text { along the } \\
\text { obturation } \\
\text { line } \\
Q_{n}, \mathrm{ml} / \mathrm{min}\end{array}$ & $\begin{array}{c}\text { Equivalent } \\
\text { diameter } \\
\text { of hole } \\
\text { along the } \\
\text { obturation } \\
\text { line, } d, \mathrm{~mm}\end{array}$ & $\begin{array}{c}\text { Coeffi- } \\
\text { cient } \\
\text { of con- } \\
\text { sumption } \\
K_{p}\end{array}$ & $\begin{array}{c}\text { Coeffi- } \\
\text { cient of } \\
\text { insula- } \\
\text { tion } K_{u}\end{array}$ & $\begin{array}{c}\text { Coeffi- } \\
\text { cient of } \\
\text { protec- } \\
\text { tion } \\
K_{z}\end{array}$ \\
\hline 1 & 315 & 1.3 & 2.0 & 5.1 & 80 \\
2 & 210 & 0.9 & 3.1 & 7.2 & 115 \\
3 & 210 & 0.9 & 3.1 & 7.2 & 115 \\
4 & 315 & 1.3 & 2.0 & 5.1 & 80 \\
5 & 315 & 1.3 & 2.0 & 5.1 & 80 \\
6 & 420 & 1.5 & 1.5 & 4.3 & 65 \\
\hline
\end{tabular}

it is required to have obligatory tests for the adequacy of each selected RPD protection. Consequently, as a result of RPD testing under working conditions, each worker can ask his/her employer to replace one respirator for another to have the required protection level.

The proposed method may be applied as alternative to costly tests of protective properties of respirators in terms of special-purpose test aerosols. It is convenient for preliminary evaluation of the protective properties of filtering half-masks in order to prevent using low-quality RPD while carrying out human tests in special-purpose chambers. Moreover, one of the areas is the training of workers how to use RPD properly under working conditions. It is of special importance in the case of Lepestok-type respirators. According to DSTU EN 529:2006, the procedure of training is compulsory; its organization is a mandatory condition for high-quality respiratory protection of workers while using the proposed method.

The following results have been obtained from the research:

+ A calibration line of the relation between pressure difference $\Delta p$ and air consumption through the gap $Q_{n}$ for the filtering half-masks of Lepestok-type has been plotted;

+ Dependence of the protection coefficient upon the insulation coefficient for the Lepestok-type respirators has been determined;

+ The protection coefficient has been proved to be directly proportional to the consumption coefficient and inversely proportional to the resistance coefficient of filtering materials;

+ The filtering half-masks of Lepestok type have been found to have a considerably lower coefficient of protection as compared with the Snezhok half-masks; 
+ The main reason for the degradation of protective properties, i.e. the complexity of uniform arrangement of folds along the obturation line, has been substantiated;
+ It has been proved that the method may be used to train the workers how to use RPD properly at the production site, according to DSTU EN 529:2006.

\section{REFERENCES}

1. Prechistenskii, S. A. (1961). Radioaktivnyie vybrosy v atmosferu. Proektirovaniie ustanovok dia ochistki vybrosov ot aerozolei i gazov. Moskva.

2. Ogorodnikov, B. I. (1973). Ulavlivamiie radioaktivnykh aerozolei voloknistymi filtruiushchimi materialami. Moskva.

3. Ogorodnikov, B. I. (2006). Radioaktivnyie aerozoli obiekta "Ukrytiie" (obzor): Ch. 5. Sredstva ulavlivaniia i analiza aerozolei. Radioaktionyie aerozoli v liogkikh. Chernobyl.

4. Nancy Bollinger, M. S. (2004). NIOSH Respirator Selection Logic. Columbia Parkway Cincinnati.

5. Luinenburg, D. M., Mullins, E. H., Danisch, S. G., Nelson, T. J. (2003). Evaluation of a Quantitative Fit Testing Method for N95 Filtering Facepiece Respirators. American Industrial Hygiene Association Journal, 64(4), 480-486.

6. Zhuang, Z., Coffey, C. C., Jensen, P. A., Campbell, D. L., Lawrence, R. B., Myers, W. R. (2004). Correlation Between Quantitative Fit Factors and Workplace Protection Factors Measured in Actual Workplace Environments at a Steel Foundry. American Industrial Hygiene Association Journal, 64(6), 730-739.

7. Holton, P. M., Tackett, D. L., Willeke, K. (1987). Particle Size-Dependent Leakage and Losses of Aerosols in Respirators. American Industrial Hygiene Association Journal, 48(10), 848-854.

8. Patricia, M. H., Willeke, K. (1987). The Effect of Aerosol Size Distribution and Measurement Method on Respirator Fit. American Industrial Hygiene Association Journal, 48(10), 855-860.

9. Coffey, C. C., Lawrence, R. B., Zhuang, Z., Campbell, D. L., Jensen, P. A., Myers, W. R. (2002). Comparison of five methods for fit-testing N95 filtering-facepiece respirators. Appl. Occup. Environ. Hyg., 17, 723-730.

10. Kaptsev, V. A., Chirkin, A. V. (2015). Ob otsenke effektivnosti sredstv individualnoi zashchity organov dykhaniia. Bezopasnost v tekhnosfere, 5, 7-14.

11. Han, D., Xu, M., Foo, S., Pilacinski, W., Willeke, K. (1991). Simplified Pressure Method for Respirator Fit Testing. American Industrial Hygiene Association Journal, 52(8), 305-308.

12. Janssen, L. L., Luinenburg, M. D., Mullins, H. E., Nelson, T. J. (2002). Comparison of Three Commercially Available Fit-Test Methods. American Industrial Hygiene Association Journal, 63(6), 762-767.

13. Hinds, W. C. (1987). Performance of dust respirators with facial seal leaks experimental. American Industrial Hygiene Association Journal, 48, 836-842.

14. Carpenter, D. R., Willeke, K. (1988). Noninvasive, Quantitative Respirator Fit Testing through Dynamic Pressure Measurement. American Industrial Hygiene Association Journal, 49(10), 485-491.

Received 23.11.17

\section{B.I. Голінько, С.І. Чеберячко, О.О. Яворська}

Державний вищий навчальний заклад «Національний гірничий університет», просп. Д. Яворницького, 19, Дніпро, 49600, Україна,

+380 56744 7339, rector@nmu.org.ua

\section{ОЦНКА ЗАХИСНИХ ВЛАСТИВОСТЕЙ ФІЛЬТРУЮЧИХ ПІВМАСОК ЗА ДОПОМОГОЮ ВИМІРЮВАННЯ ПЕРЕПАДУ ТИСКУ}

Вступ. Важливою характеристикою респіратора є здатність його напівмаски захищати органи дихання від різноманітних забруднень в атмосфері за рахунок щільного прилягання до обличчя.

Проблематика. Одним з низьковартісних і простих методів альтернатив діагностики захисних властивостей напівмасок за допомогою спеціальних тест-аерозолів є підтримання постійного перепаду тиску під маскою. Він базується на визначенні кількості повітря, що підсмоктується через щілини, при створенні розрядження у підмасочному просторі. Однак, немає рекомендацій щодо можливостей цього методу в оцінюванні ізолюючих властивостей легких фільтруючих напівмасок, з-під яких не можна відкачати повітря.

Мета. Розробити спрощений метод оцінювання захисних властивостей напівмасок з використанням вимірювання ступеню розрідження повітря під фільтрувальною напівмаскою, який дозволяє встановити їі ізолюючі властивості та коефіцієнт захисту. 
Матеріали й методи. Коефіцієнт захисту респіратора можна оцінити за кількістю повітря, що проходить через фільтруючий матеріал і щілини з відомим коефіцієнтом проникнення і підсосу. Останній обчислюється як коефіцієнт аспірації в щілину відомої довжини. Витрати повітря визначаються експериментально за різницею тисків між герметично розташованою напівмаскою на манекені та розташованими по її периметру обтюрації трубочками з відомим діаметром.

Результати. Побудована калібрувальна шкала взаємозв'язку перепадів тиску і витрат повітря через зазор для фільтруючих напівмасок. Розраховано коефіцієнти ізоляції та захисту респіраторів типу «Лепесток». Встановлено, що коефіцієнт захисту прямопропорційно залежить від співвідношення витрат повітря через фільтр і щілини між обличчям і напівмаскою по смузі обтюрації.

Висновки. Доведено, що метод визначення захисних властивостей фільтруючих напівмасок вимірюванням перепадів тиску можна використовувати як альтернативу високовартісній діагностиці якості засобів індивідуального захисту органів дихання, а також застосовувати при підборі та навчанні працівників правильній експлуатації респіраторів на виробництві відповідно до вимог EN 529: 2006.

Ключові слова: концентрація шкідливих речовин, коефіцієнт проникнення, витрата повітря, захисні властивості, фільтрувальна напівмаска.

\section{В.И. Голинько, С.И. Чеберячко, Е.А. Яворская}

Государственное высшее учебное заведение «Национальный горный университет», просп. Д. Яворницкого, 19, Днепр, 49600, Украина,

$$
\text { +380 } 56744 \text { 7339, rector@nmu.org.ua }
$$

\section{ОЦЕНКА ЗАЩИТНЫХ СВОЙСТВ ФИЛЬТРУЮЩИХ ПОЛУМАСОК С ПОМОЩЬЮ ИЗМЕРЕНИЯ ПЕРЕПАДА ДАВЛЕНИЯ}

Введение. Важной характеристикой респиратора является способность его полумаски ограждать органы дыхания от различных загрязнений атмосферы за счет плотного прилегания к лицу.

Проблематика. Одним из недорогих и простых методов альтернативой диагностики защитных свойств полумасок с помощью специальных тест-аэрозолей является поддержание постоянного перепада давления под маской. Он основан на определении количества подсасываемого воздуха через зазоры при создании разряжения в подмасочном пространстве. Однако, нет рекомендаций о возможности оценить с помощью этого метода изолирующие свойства легких фильтрующих полумасок, из-под которых нельзя откачать воздух.

Цель. Разработать упрощенный метод оценки защитных свойств полумасок с использованием измерения разрежения воздуха под фильтрующей полумаской, позволяющий установить ее изолирующие свойства и коэффициент защиты.

Материалы и методы. Коэффициент защиты респиратора можно оценить по количеству проходящего воздуха через фильтрующий материал и зазоры с известным коэффициентом проникания и подсоса. Последний вычисляется как коэффициент аспирации в щель известной длины. Расходы воздуха определяются экспериментально по разности давления между герметически расположенной полумаской на манекене и с расположенными по ее периметру обтюрации трубочками с известным диаметром.

Результаты. Построена калибровочная шкала взаимосвязи перепада давления и расхода воздуха через зазор для фильтрующих полумасок. Рассчитаны коэффициенты изоляции и защиты респираторов типа «Лепесток». Установлено, что коэффициент защиты прямопропорционально зависит от соотношения расходов воздуха через фильтр и зазоры между лицом и полумаской по полосе обтюрации.

Выводы. Доказано, что метод определения защитных свойств фильтрующих полумасок по измерению перепадов давления можно использовать как альтернативу дорогостоящей диагностике качества средств индивидуальной защиты органов дыхания, а также использовать при подборе и обучении работников правильной эксплуатации респираторов на производстве в соответствии с требованиями EN 529:2006.

Ключевые слова: концентрация вредных веществ, коэффициент проникания, расход воздуха, защитные свойства, фильтрующая полумаска. 